\title{
THE INCIDENCE AND CHARACTERISTICS OF LEWY BODIES IN IDIOPATHIC PARALYSIS AGITANS (PARKINSON'S DISEASE)
}

\author{
BY \\ J. BETHLEM and W. A. DEN HARTOG JAGER \\ From the Neurological Clinic, University of Amsterdam
}

In 1913, the Breslau neurologist Lewy described globular inclusions of cytoplasmic condensations in the cells of the nucleus substantiae innominatae and the dorsal vagal nucleus in paralysis agitans. These cell inclusions have since been described by many other investigators. In 1923, Lewy also found them in the pigmented ganglion cells of the substantia nigra in Parkinson's disease. Trétiakoff (1919) found these "Lewy bodies" in six out of nine typical cases of paralysis agitans, and in one atypical case. Foix and Nicolesco (1925) described them as found in an unspecified number of cases of Parkinson's disease. Redlich (1930) found Lewy bodies in the substantia nigra in two cases of postencephalitic Parkinsonism and in one case of Parkinson's disease. Klaue (1940), on the basis of both clinical and anatomical pathological findings in a large amount of material, advocated the unitarian theory regarding the aetiology of idiopathic and postencephalitic Parkinsonian conditions. He found identical neuropathological changes in both instances. Van Valkenburg (1941) described one case of idiopathic paralysis agitans with Lewy bodies in the pigmented cells of the brain-stem. Beheim-Schwarzbach (1952) found Lewy bodies in 16 cases of Parkinson's disease and in 10 cases of senescence with no Parkinsonian signs. She found no Lewy bodies in 13 cases of postencephalitic Parkinsonism. She elaborated the material previously described by Hassler (1938).

Greenfield and Bosanquet (1953) examined 19 cases of idiopathic paralysis agitans. In nine cases it was possible to examine the substantia nigra and the locus coeruleus; Lewy bodies were found in both. In nine cases, only the substantia nigra was available but Lewy bodies were invariably found in it. In the remaining case, only the locus coeruleus could be examined and Lewy bodies were found. In all these cases of idiopathic paralysis agitans, therefore, Lewy bodies were demonstrable. No Lewy bodies were found in 10 cases of postencephalitic Parkinsonism. They were demon- strated in two out of five cases of atypical Parkinsonism.

A single atypical inclusion (not a genuine Lewy body) was found in the cytoplasm of a locus coeruleus cell in only one out of 22 patients aged 50-88, with no clinical signs of Parkinsonism. Rövéti (1956) found no Lewy bodies in eight postencephalitic cases, but did find them in two out of 15 psychiatric patients with no clinical signs of Parkinsonism.

In so far as the authors have presented numerical data, the findings from the literature have been tabulated in Table $I$.

TABLE 1

FINDING OF LEWY BODIES ABSTRACTED FROM THE LITERATURE

\begin{tabular}{|c|c|c|c|c|c|c|}
\hline \multirow{2}{*}{ Authors } & \multicolumn{2}{|c|}{$\begin{array}{c}\text { Idiopathic } \\
\text { Paralysis } \\
\text { Agitans }\end{array}$} & \multicolumn{2}{|c|}{$\begin{array}{c}\text { Post- } \\
\text { encephalitic } \\
\text { Parkinsonism }\end{array}$} & \multicolumn{2}{|c|}{$\begin{array}{c}\text { Control } \\
\text { Cases }\end{array}$} \\
\hline & $\begin{array}{l}\text { No. of } \\
\text { Cases }\end{array}$ & $\begin{array}{l}\text { Lewy } \\
\text { Bodies }\end{array}$ & $\begin{array}{c}\text { No. of } \\
\text { Cases }\end{array}$ & $\begin{array}{c}\text { Lewy } \\
\text { Bodies }\end{array}$ & $\begin{array}{l}\text { No. of } \\
\text { Cases }\end{array}$ & $\begin{array}{c}\text { Lewy } \\
\text { Bodies }\end{array}$ \\
\hline Trétiakoff (1919) & 9 & 6 & 3 & 0 & - & - \\
\hline Redlich (1930) & 1 & 1 & 2 & 2 & - & - \\
\hline van Valkenburg & 1 & 1 & - & - & - & - \\
\hline Beheim- & 16 & 16 & 13 & 0 & 30 & 10 \\
\hline Greenfield and & 19 & 19 & 10 & 0 & 22 & 0 \\
\hline Röveti (1956) & - & - & 8 & $\mathbf{0}$ & 15 & 2 \\
\hline Total & 46 & 43 & 36 & 2 & 67 & 12 \\
\hline
\end{tabular}

Greenfield and Bosanquet, however, stated (1953):

"The combination of loss of cells in certain fairly well-defined cell groups in the substantia nigra, with numerous inclusions of the Lewy type, as defined by us, in the pigmented cells of the brain-stem is, however, quite characteristic of paralysis agitans and occurs, so far as we know, in no other disease."

The pathogenesis of Lewy bodies is still obscure. Generally speaking, cytoplasmic inclusions are found in man due to virus infections or after poisoning by heavy metals. 


\section{Viral Inclusions}

Many virus infections in man give rise to cytoplasmic inclusions outside the central nervous system. Only human rabies causes inclusions exclusively localized in the cytoplasm of the ganglion cells of the central nervous system. In addition there are some conditions in which the human nervous system is known to contain both intranuclear and cytoplasmic inclusions, viz., cytomegalic inclusion disease and Dawson's encephalitis.

Various inclusion bodies have been demonstrated to consist of a colony of elementary bodies surrounded by a matrix. By staining with Victoria blue, Herzberg (1934) was able to demonstrate elementary bodies in inclusions found in smallpox, chickenpox, ectromelia, and canary pox. Elementary bodies have been demonstrated by the electron microscope in cases of cowpox, ectromelia, and molluscum contagiosum (Gaylord and Melnick, 1953), herpes simplex, cowpox, and fowl pox (Morgan, Ellison, Rose, and Moore, 1954). The ability to show nucleo-proteins, ribonucleic acid (R.N.A.) or deoxyribonucleic acid (D.N.A.), in inclusion bodies also constitutes an argument in favour of the presence of virus particles in the inclusions. On the other hand, there are the investigations of Croissant, Lépine, and Wyckoff (1955) and Sourander (1956) in Negri bodies. Croissant et al. were unable to demonstrate elementary particles in Negri bodies by electron microscopy. Sourander, using the ultra-violet absorption method, was also unable to demonstrate R.N.A. or D.N.A. in Negri bodies. These investigations indicate that, in virus infections, inclusion bodies may consist either of colonies or elementary bodies surrounded by a matrix or, as in the case of Negri bodies, they may be the product of a reaction of the cellular protoplasm to the virus infection.

\section{Non-viral Inclusions}

Inclusions may be encountered in cases of heavy metal poisoning. Pappenheimer and Maechling (1934) and Hartz and van der Sar (1944) found intranuclear and cytoplasmic inclusions in the renal epithelium of patients treated with injections of bismuth. Pappenheimer and Maechling (1934) and Wolman (1954) succeeded in producing these bodies experimentally in animals. Finner and Calvery (1939) and Wolman (1954) described intranuclear and cytoplasmic inclusions in renal epithelium in animals following experimental lead poisoning. In 1949, Wachstein found intranuclear inclusions in the renal epithelium and liver cells of a child who died of lead poisoning. Olitsky and Harford (1937) provoked intranuclear inclusions in experimental animals with the aid of aluminium. These inclusions contained no D.N.A., a fact confirmed by Wolman (1954) with regard to bismuth and lead inclusions. Finner and Calvery (1939) demonstrated that inclusions found in lead poisoning cases contained lead. With regard to other inclusions caused by heavy metal poisoning, the metal in question has not been demonstrated in the inclusions.

The present investigation was made in order to establish, on the basis of our own materiai, the extent to which Lewy bodies can be considered characteristic of idiopathic paralysis agitans. An attempt was also made to determine the nature of the inclusion.

\section{Material and Methods}

Our material consisted of 15 cases of idiopathic paralysis agitans and four cases of postencephalitic Parkinsonism. All the necropsy material was obtained during the period 1956-59.

The four cases of postencephalitic Parkinsonism were clinically diagnosed as such on the basis of a definite history of encephalitis reported in 1918-20.

Examination of the 19 cerebral specimens invariably included the following parts: the substantia nigra (with the exception of three cases in which it had been used for other purposes), the locus coeruleus, the substantia innominata, the hippocampus, area 4 and area 6 , and sections obtained from the frontal, parietal, and occipital lobes, the cerebellar hemispheres, the nucleus dentatus, and the cerebellar vermis.

Since our material included only four cases of postencephalitic Parkinsonism, the locus coeruleus in these cases was examined in complete serial sections. In addition, 10-20 sections through the locus coeruleus from 20 patients aged $60-80$ without Parkinsonian symptoms were examined. These patients were clinically observed for several weeks or months, and examined by two or several neurologists.

The blocks were embedded in paraffin, celloidin, or ice.

The Lewy bodies were examined using: (1) haematoxylin and eosin, Van Gieson, Masson's trichrome, Lendrum's phloxine tartrazine, periodic-acid-Schiff, Giemsa, Sudan III, Sudan black, iodine, Ziehl-Neelsen, Gram, and Bielschowsky staining and phase-contrast microscopy; (2) Nissl's cresyl violet, Weigert-Pal, Marchi, Mallory aniline blue orange G., and Dominici staining and fluorescence microscopy; (3) coupled tetrazonium reaction for proteins, Best's stain for glycogen, mucicarmine for mucin, Weigert's stain for fibrin, Turnbull's stain for iron, Kossa's stain for calcium, Feulgen reaction for D.N.A., and Einarson's stain for R.N.A. and D.N.A. and ultra-violet microscopy and microradiography.

The locus coeruleus of one case of idiopathic paralysis agitans (No. 501) was fixed in $10 \%$ formaldehyde solution and stained according to Giemsa and with $1 \%$ and $3 \%$ Victoria blue solution according to the method of 
Herzberg. The locus coeruleus of another case of idiopathic paralysis agitans (No. 533) was fixed in a Carnoy solution for three days, and likewise stained according to Giemsa and with $1 \%$ and $3 \%$ Victoria blue solution. A different part of the formaldehyde-fixed locus coeruleus was submitted to the influence of a $1 \%$ trypsin solution for 10 minutes, one hour, and 24 hours, respectively, and then stained in the manner described.

In five cases of idiopathic paralysis agitans (Nos. 490, $501,509,516,524)$ one or both areas of the substantia nigra were removed within 55 to 190 minutes of death. Immediately afterwards, the Griffith tube was used to prepare a $10 \%$ suspension of penicillin-streptomycin broth, containing $100 \mathrm{u}$. penicillin per $\mathrm{ml}$. and $100 \mu \mathrm{g}$. streptomycin per $\mathrm{ml}$; $0.10 \mathrm{ml}$. of this suspension was inoculated intracerebrally into 12 grown mice, 10 grown rats, two guinea-pigs, and two pigeons; $0.5 \mathrm{ml}$. of the suspension was inoculated intracerebrally into two Cynomolgus monkeys and two rabbits.

Two controls of each animal species were included in the investigation and were not inoculated. The animals were sacrificed two months after intracerebral inoculation; only the monkeys were sacrificed after six months. The brains were fixed in formaldehyde $(10 \%$ solution) and examined in frontal sections after haematoxylin-eosin staining.

\section{Results}

Incidence of Lewy Bodies.-Lewy bodies were found in the locus coeruleus and/or the substantia nigra in each of the 15 cases of idiopathic paralysis agitans (Figs. 1, 2, and 3). In nine of these 15 cases, moreover, they were also seen in the ganglion cells of the substantia innominata (Fig. 4). In the four cases of postencephalitic Parkinsonism, no inclusions were found in the substantia nigra, substantia innominata, and the locus coeruleus (the latter examined in serial sections). None of the sections of the 20 control cases contained a Lewy

TABLE II

INCIDENCE OF LEWY INCLUSIONS

\begin{tabular}{|c|c|c|c|c|c|}
\hline No. & Sex & Age & $\begin{array}{c}\text { Locus } \\
\text { Coeruleus }\end{array}$ & $\begin{array}{c}\text { Substantia } \\
\text { Nigra }\end{array}$ & $\begin{array}{l}\text { Substantia } \\
\text { Innominata }\end{array}$ \\
\hline \multicolumn{4}{|c|}{ Idiopathic Paralysis Agitans } & & \\
\hline $\begin{array}{l}458 \\
477 \\
478 \\
509 \\
510 \\
519 \\
524 \\
533 \\
534 \\
555 \\
556 \\
561 \\
490 \\
501 \\
516\end{array}$ & $\begin{array}{l}\mathbf{M} \\
\mathbf{F} \\
\mathbf{F} \\
\mathbf{M} \\
\mathbf{M} \\
\mathbf{F} \\
\mathbf{M} \\
\mathbf{M} \\
\mathbf{M} \\
\mathbf{F} \\
\mathbf{F} \\
\mathbf{F} \\
\mathbf{F} \\
\mathbf{F} \\
\mathbf{M}\end{array}$ & $\begin{array}{l}59 \\
60 \\
61 \\
74 \\
73 \\
76 \\
71 \\
82 \\
88 \\
73 \\
63 \\
72 \\
72 \\
75 \\
79\end{array}$ & $\begin{array}{l}+ \\
+ \\
+ \\
+ \\
+ \\
+ \\
+ \\
+ \\
+ \\
+ \\
+ \\
+ \\
+ \\
+ \\
+\end{array}$ & $\begin{array}{c}+ \\
+ \\
+ \\
+ \\
+ \\
+ \\
+ \\
+ \\
+ \\
+ \\
+ \\
\text { Used } \\
\text { for other } \\
\text { purposes }\end{array}$ & $\begin{array}{l}+ \\
+ \\
+ \\
- \\
- \\
\bar{t} \\
- \\
+ \\
- \\
+ \\
+ \\
+ \\
+\end{array}$ \\
\hline \multicolumn{6}{|c|}{ Post-encephalitic Parkinsonism } \\
\hline $\begin{array}{l}446 \\
447 \\
568 \\
569\end{array}$ & $\begin{array}{l}\mathbf{M} \\
\mathbf{M} \\
\mathbf{M} \\
\mathbf{F}\end{array}$ & $\begin{array}{l}60 \\
68 \\
37 \\
57\end{array}$ & $\begin{array}{l}- \\
- \\
-\end{array}$ & $\begin{array}{l}- \\
- \\
-\end{array}$ & $\begin{array}{l}- \\
- \\
-\end{array}$ \\
\hline
\end{tabular}

TABLE III

CONTROL CASES

\begin{tabular}{|c|c|c|c|c|}
\hline No. & Sex & Age & Post-mortem Diagnosis & $\begin{array}{l}\text { Lewy Bodies } \\
\text { in Locus } \\
\text { Coeruleus }\end{array}$ \\
\hline $\begin{array}{l}481 \\
488\end{array}$ & $\begin{array}{l}\mathbf{M} \\
\mathbf{F}\end{array}$ & $\begin{array}{l}60 \\
60\end{array}$ & $\begin{array}{l}\text { Amyotrophic lateral sclerosis } \\
\text { Thrombosis a. cerebri pos- }\end{array}$ & - \\
\hline $\begin{array}{l}521 \\
505\end{array}$ & $\begin{array}{l}\mathbf{M} \\
\mathbf{F}\end{array}$ & $\begin{array}{l}60 \\
62\end{array}$ & $\begin{array}{l}\text { Taboparalysis } \\
\text { Subacute cerebellar degenera- } \\
\text { tion associated with visceral } \\
\text { carcinoma }\end{array}$ & - \\
\hline 419 & $\mathbf{M}$ & 63 & $\begin{array}{l}\text { Polio-encephalitis haemor- } \\
\text { rhagica }\end{array}$ & - \\
\hline 469 & $\mathbf{F}$ & 64 & Syringomyelia & 一 \\
\hline 511 & $\mathbf{F}$ & 64 & $\begin{array}{l}\text { Polio-encephalitis haemor- } \\
\text { rhagica }\end{array}$ & - \\
\hline 489 & $\mathbf{F}$ & 66 & $\begin{array}{l}\text { Granular cell degeneration of } \\
\text { cerebellum associated with } \\
\text { tuberculosis }\end{array}$ & - \\
\hline 475 & $\mathbf{F}$ & 67 & $\begin{array}{l}\text { Arteriosclerosis of the cere- } \\
\text { brum }\end{array}$ & 一 \\
\hline 553 & $\mathbf{M}$ & 67 & $\begin{array}{l}\text { Compression of medullae by } \\
\text { vertebral metastasis }\end{array}$ & - \\
\hline $\begin{array}{l}438 \\
500\end{array}$ & $\begin{array}{l}\mathbf{M} \\
\mathbf{M}\end{array}$ & $\begin{array}{l}68 \\
68\end{array}$ & $\begin{array}{l}\text { Thrombosis a. cerebri media } \\
\text { Arteriosclerosis of the cere- } \\
\text { brum }\end{array}$ & $\overline{-}$ \\
\hline $\begin{array}{l}551 \\
175 \\
474 \\
526\end{array}$ & $\begin{array}{l}\mathbf{F} \\
\mathbf{M} \\
\mathbf{F} \\
\mathbf{F}\end{array}$ & $\begin{array}{l}69 \\
70 \\
71 \\
72\end{array}$ & $\begin{array}{l}\text { Thrombosis a. cerebri media } \\
\text { Cerebellar apoplexy } \\
\text { Tabes dorsalis } \\
\text { Arteriosclerosis of the cere- } \\
\text { brum }\end{array}$ & $\overline{-}$ \\
\hline $\begin{array}{l}554 \\
402 \\
550\end{array}$ & $\begin{array}{l}\mathbf{F} \\
\mathbf{M} \\
\mathbf{M}\end{array}$ & $\begin{array}{l}74 \\
78 \\
78\end{array}$ & $\begin{array}{l}\text { Multiple cerebral metastases } \\
\text { Thrombosis a. cerebri media } \\
\text { Compression of medulla by } \\
\text { vertebral metastasis }\end{array}$ & - \\
\hline 331 & $\mathbf{F}$ & 80 & Multiple cerebral softenings & - \\
\hline
\end{tabular}

body in the ganglion cells of the left and the right locus coeruleus (Tables II and III).

Morphology and Staining Reactions.-The morphology of the Lewy bodies was previously described in detail by Greenfield and Bosanquet, and need not be gone into again in this paper. They always have a pale halo and the larger inclusions may contain an acidophilic central core. Our methods enumerated in Group 1 yielded results almost identical to those mentioned by these authors. The results of the methods listed in Groups 2 and 3 are presented in Table IV.

TABLE IV

MORPHOLOGY AND STAINING REACTIONS

\begin{tabular}{|c|c|c|}
\hline $\begin{array}{c}\text { Stain } \\
\text { or Method }\end{array}$ & $\begin{array}{c}\text { Main } \\
\text { Inclusion Body }\end{array}$ & $\begin{array}{l}\text { Central } \\
\text { Core }\end{array}$ \\
\hline $\begin{array}{l}\text { Nissl's cresyl violet } \\
\text { Weigert-Pal } \\
\text { Marchi } \\
\text { Mallory A.B.O.G. } \\
\text { Dominici } \\
\text { Victoria blue } \\
\text { Fluorescence microscopy } \\
\text { Proteins (coupled tetrazonium } \\
\text { reaction) } \\
\text { Glycogen (Best) } \\
\text { Mucin (mucicarmine) } \\
\text { Fibrin (Weigert) } \\
\text { Iron (Turnbull) } \\
\text { Calcium (Kossa) } \\
\text { D.N.A. (Feulgen) } \\
\text { R.N.A. and D.N.A. (Einarson) } \\
\text { Uitra-violet microscopy 260- } \\
\text { 280, 325mp } \\
\text { Microradiography for heavy } \\
\text { metals }\end{array}$ & $\begin{array}{l}\text { Unstained } \\
\text { Unstained } \\
\text { Faint yellow } \\
\text { Blue } \\
\text { Unstained } \\
\text { Unstained } \\
\text { No fluorescence } \\
\text { Unstained } \\
\text { Negative } \\
\text { Negative } \\
\text { Negative } \\
\text { Negative } \\
\text { Negative } \\
\text { Negative } \\
\text { Negative } \\
\text { No absorption } \\
\text { No absorption }\end{array}$ & $\begin{array}{l}\text { Faint green-blue } \\
\text { Dark Blue } \\
\text { Yellow-brown } \\
\text { Bright red } \\
\text { Bright red } \\
\text { Dark blue } \\
\text { No fluorescence } \\
\text { Positive } \\
\text { Negative } \\
\text { Negative } \\
\text { Negative } \\
\text { Negative } \\
\text { Negative } \\
\text { Negative } \\
\text { Negative } \\
\text { No absorption } \\
\text { No absorption }\end{array}$ \\
\hline
\end{tabular}




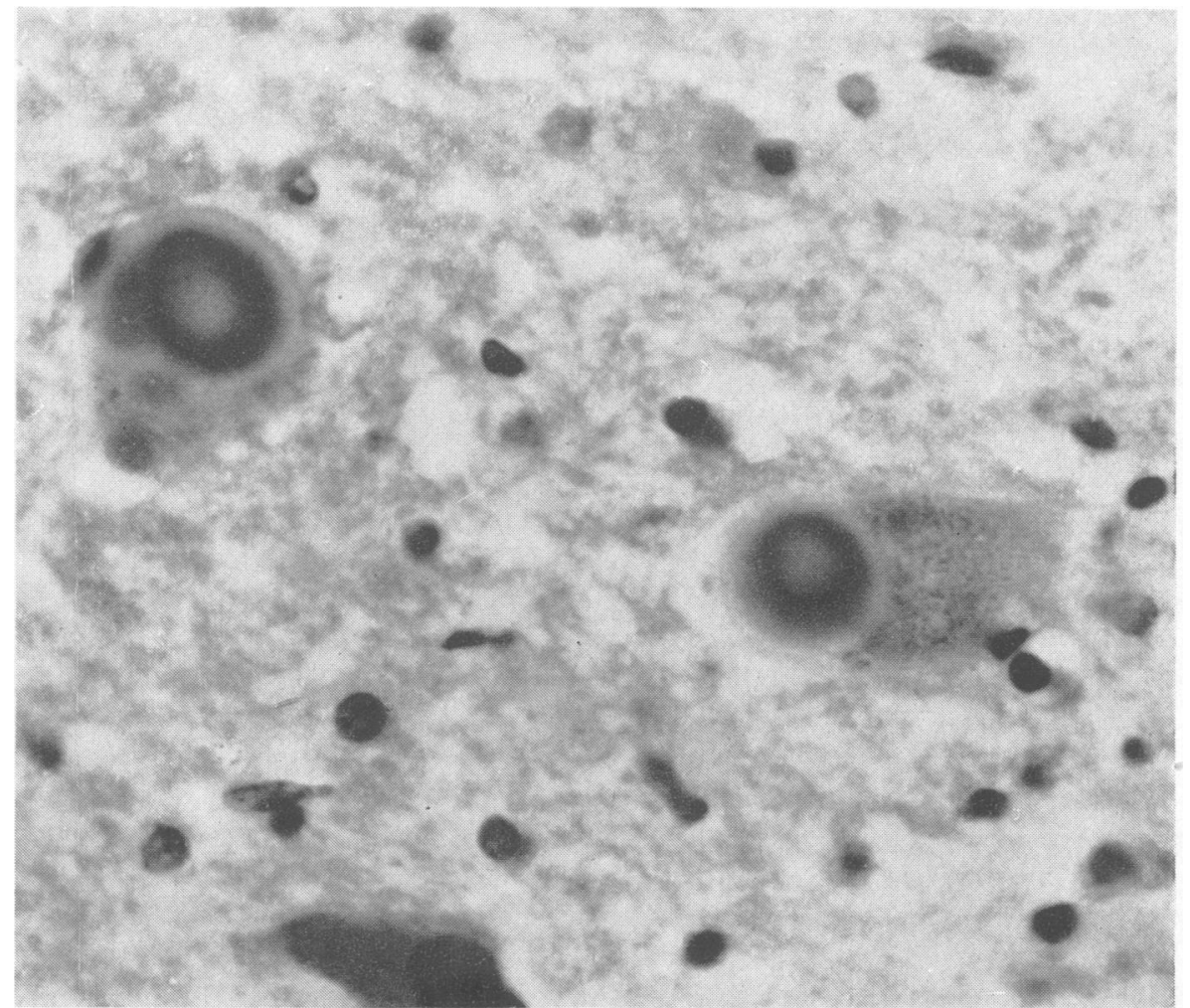

Fig. 1.-Typical Lewy bodies in two pigmented ganglion cells of locus coeruleus. Haematoxylin-eosin.

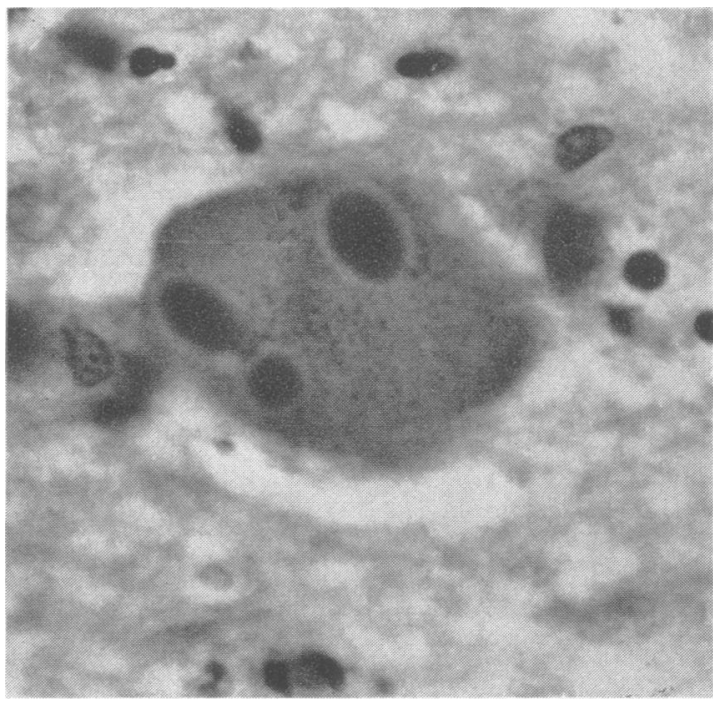

FIG. 2.-Three Lewy inclusions in one pigmented ganglion cell of locus coeruleus. Haematoxylin-eosin.

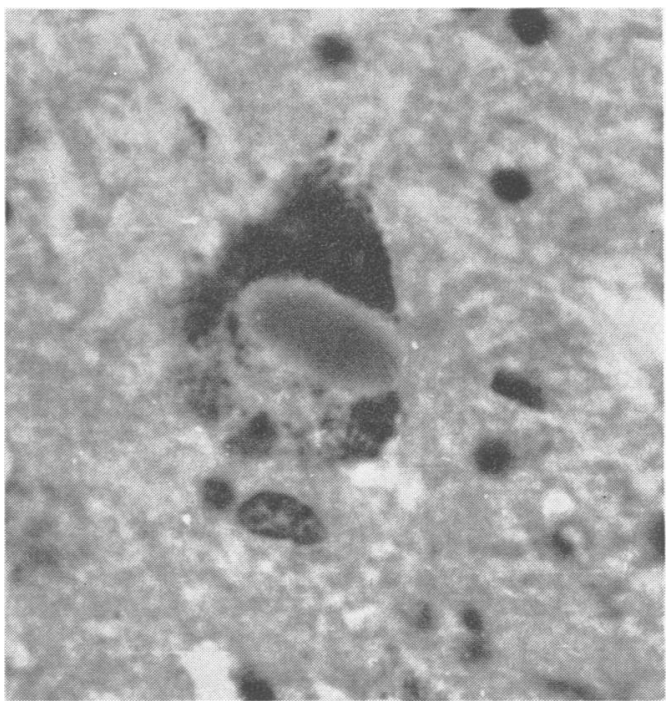

FIG. 3.-Oval Lewy body in pigmented cell of substantia nigra. Haematoxylin-eosin. 


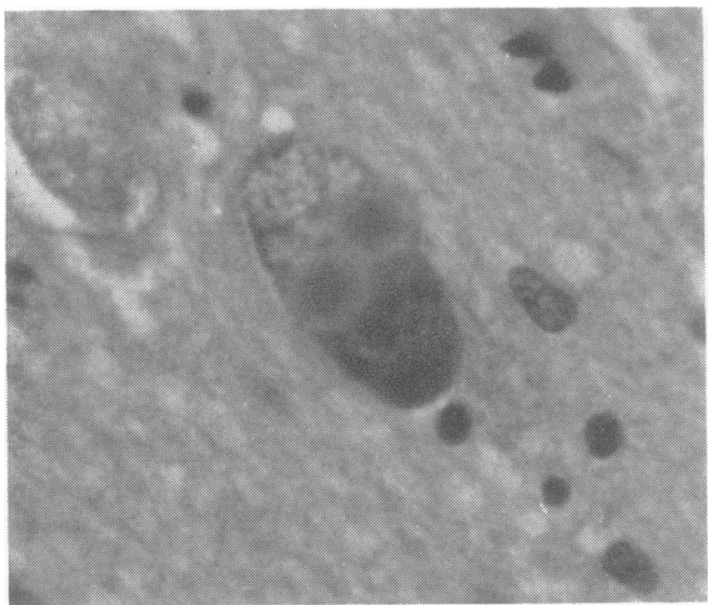

FIG. 4.-Two Lewy bodies in ganglion cell of substantia innominata. Haematoxylin-eosin.

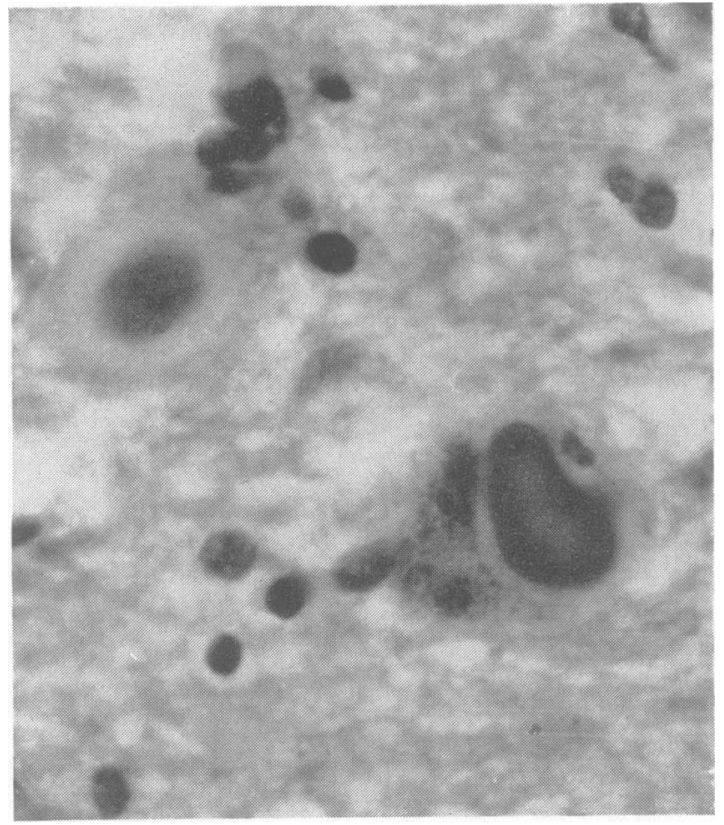

Fig. 6.-Pear-shaped Lewy inclusion in pigmented cell of substantia nigra. In the left upper corner of the picture a so-called extracellular body with a broad, pale halo is seen. Haematoxylineosin.

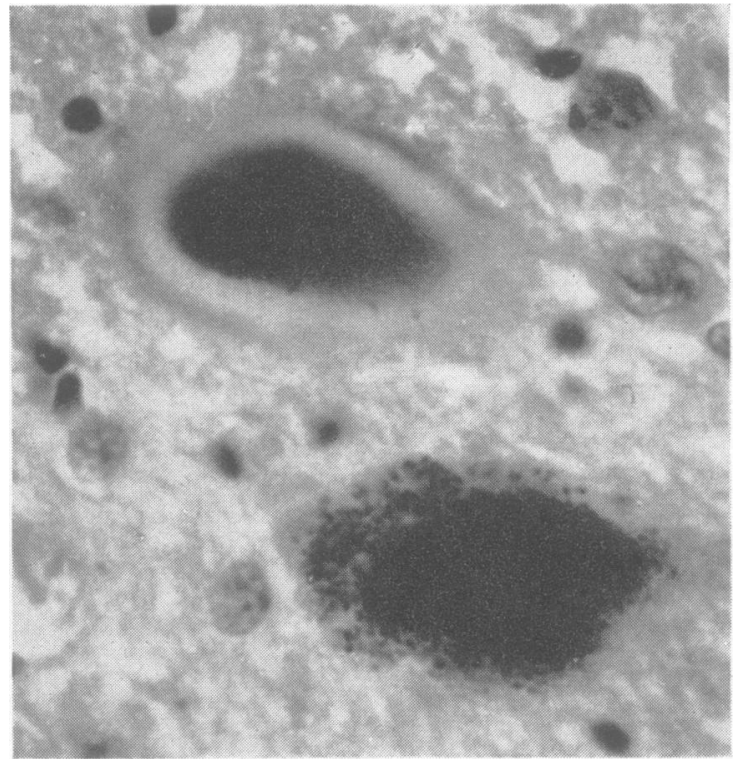

So-called extracellular Lewy body in locus coeruleus. Haematoxylin-eosin.

FIG. 7--Irregular shaped Lewy inclusions in pigmented cell of substantia nigra. Forms like these are rarely seen. Haematoxylin-eosin.

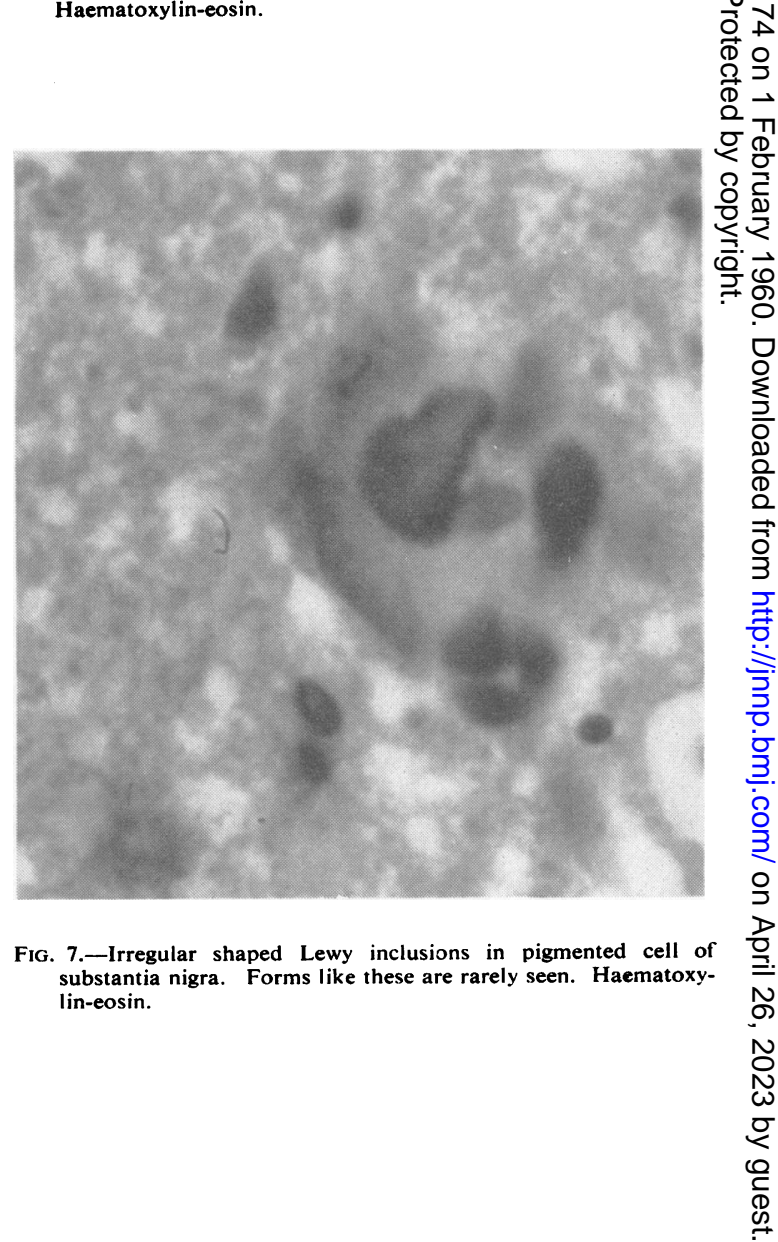


Mallory's aniline blue orange G. and Dominici's stains gave excellent contrasts with a bright red central core. Gram staining occasionally showed a Gram-positive central core, and the Ziehl-Neelsen stain sometimes showed the central core to be acidfast. According to Weigert-Pal, the central core stained a deep black-blue, whereas Marchi's stain caused no blackening of the body or the central core.

The dimensions of the Lewy bodies ranged from 2 to $40 \mu$. Extracellular forms (Fig. 5) were repeatedly encountered but, when examined in serial sections, proved to be localized in degenerated ganglion cells. Often in such cases only a few melanin pigment granules are found round the body. Lewy bodies of irregular rather than globular or oval shape are an exceptional finding (Figs. 6 and 7). The features seen by phase-contrast and fluorescence microscopy afforded no new information on the structure of the Lewy body.

Histochemistry.-A Lewy body contains no lipids and no mucopolysaccharides, nor does it contain glycogen, mucin, fibrin, or calcium. The Turnbull test for iron was likewise negative. Absorption at microradiographic examination was so slight as to warrant the conclusion that a Lewy body contains no other heavy metals.

Danielli's coupled tetrazonium reaction showed positive staining of the central core, which indicates the presence of proteins containing aromatic alphaamino-acids. The negative periodic-acid-Schiff reaction indicates that we are not dealing with mucoproteins or glycoproteins.

The Feulgen test and Einarson's gallocyanine stain were negative, which suggests the absence of nucleoproteins. This was confirmed by the fact that Lewy bodies gave no absorption at ultra-violet microscopic examination at wavelengths of 2,600 , 2,800 , and $3,200 \AA$.

Investigation of the Elementary Bodies.-In the formaldehyde-fixed material, the central core of a Lewy body stained deep blue with Victoria blue. The structure and intensity of staining remained entirely unchanged when possible lipids were dissolved with Carnoy's solution and possible proteins by trypsin. Similar results were obtained with Giemsa staining. In none of the specimens were elementary particles observed.

Intracerebral Inoculation with Substantia Nigra Suspension.-Animals inoculated intracerebrally with a substantia nigra suspension obtained from patients with idiopathic paralysis agitans did not show a single symptom throughout the period of observation. In none of the cerebral parts examined were cytoplasmic inclusion bodies or signs of inflammation observed (Table V).
TABLE V

RESULTS OF INTRACEREBRAL INOCULATION WITH SUBSTANTIA NIGRA SUSPENSION

\begin{tabular}{c|c|c|c|c}
\hline $\begin{array}{c}\text { Case } \\
\text { No }\end{array}$ & $\begin{array}{c}\text { Duration } \\
\text { of Illness } \\
\text { (yr.) }\end{array}$ & $\begin{array}{c}\text { Interval } \\
\text { Between Death } \\
\text { and Completion } \\
\text { of Necropsy } \\
\text { (min.) }\end{array}$ & $\begin{array}{l}\text { Experimental } \\
\text { Animals }\end{array}$ & $\begin{array}{l}\text { Histological } \\
\text { Changes }\end{array}$ \\
\hline 490 & 7 & 120 & $\begin{array}{l}1 \text { monkey } \\
3 \text { mice } \\
1 \text { monkey } \\
3 \text { mice } \\
1 \text { guinea-pig } \\
8 \text { rats } \\
3 \text { mice } \\
1 \text { guinea-pig } \\
3 \text { mice } \\
2 \text { rats } \\
2 \text { rabbits } \\
2 \text { pigeons }\end{array}$ & None \\
509 & 9 & 120 & None \\
516 & $11 \frac{1}{2}$ & 180 & 55 & None \\
524 & 16 & 1 & &
\end{tabular}

\section{Comment}

The literature reveals a lack of agreement with regard to the presence or absence of Lewy bodies in the pigmented cells of the brain-stem in Parkinson's disease, postencephalitic Parkinsonism, and a control group of patients without Parkinsonian symptoms. Beheim-Schwarzbach and Greenfield and Bosanquet are the only authors to have studied this specific problem in each of the three groups mentioned on the basis of a large amount of material. They found Lewy bodies in all their cases of idiopathic paralysis agitans and in none of the cases of postencephalitic Parkinsonism. Their results are discrepant, however, as regards the control groups. Beheim-Schwarzbach found Lewy bodies in 10 out of 30 instances, whereas Greenfield and Bosanquet found no Lewy bodies in any of their 22 control cases.

Our own results are in complete agreement with those of Greenfield and Bosanquet. Lewy inclusion bodies were found in each of 15 cases of idiopathic paralysis agitans and in none of the four instances of postencephalitic Parkinsonism. Nor were they found in any of the 20 controls without Parkinsonian symptoms of the same age group as the patients with paralysis agitans.

Since Lewy described the spherical hyaline inclusions in the ganglion cells of the substantia innominata in 1913, hardly any attention has been given to this nucleus. Only Greenfield and Bosanquet described typical Lewy bodies in the substantia innominata in one of their five cases of atypical Parkinsonism. We found Lewy bodies in the substantia innominata in nine of our 15 cases of idiopathic paralysis agitans. The occurrence of Lewy bodies in this nuclear region is of great theoretical significance, as the cells of this nuclear group do not contain the melanin pigment typical of the substantia nigra and the locus coeruleus cells. We believe that the occurrence of Lewy bodies in the 
substantia nigra, locus coeruleus, and substantia innominata is a specific phenomenon of idiopathic paralysis agitans which, histologically, sharply differentiates this condition from postencephalitic Parkinsonism and neurological affections without Parkinsonian traits. In view of this, a better understanding of the nature of Lewy bodies may be the key to the pathogenesis of Parkinson's disease. Although Lewy bodies show a positive Lendrum stain, it has been established that they do not belong to the group of viral inclusions which consist of elementary particles. Elementary particles were not demonstrable in Lewy bodies by staining with Victoria blue. Moreover, Lewy bodies were not found to contain nucleoproteins. Whether they belong to the group of viral inclusions to be regarded as a product of a reaction of the cellular protoplasm to a virus infection (such as the Negri bodies) remains a question open to discussion. It is true that animal inoculations were negative. However, we used necropsy material, and it may well be that the experimental animals used were not of the appropriate species.

Since microradiography showed that the Lewy bodies contained no heavy meta's, these inclusions are not a result of storage of heavy metal, as is the case in lead poisoning.

We found that the central core of the Lewy bodies gives a positive coupled tetrazonium reaction and, therefore, consists of proteins which contain aromatic alpha-amino-acids.

\section{Summary}

In 15 cases of idiopathic paralysis agitans, Lewy bodies were invariably found in the locus coeruleus and the substantia nigra; in nine of these cases, they were also found in the cells of the substantia innominata.

In four cases of postencephalitic Parkinsonism, no Lewy bodies were found in the substantia nigra, substantia innominata, and locus coeruleus; the last-mentioned cell group was examined bilaterally in complete serial sections in each of the four cases.

In from 10 to 20 sections of the locus coeruleus from 20 patients with no clinical features of Parkinsonism, and in the age group 60-80, no Lewy bodies were found.

Lewy bodies contain no deoxyribonucleic acid or ribonucleic acid, as demonstrated by the Feulgen reaction, Einarson's stain, and ultra-violet micro- scopy. Victoria blue and Giemsa staining failed to reveal elementary particles in the Lewy bodies, not even after preceding dissolution of such proteins or lipids as might be present in the matrix.

Intracerebral inoculations of substantia nigra suspension obtained within 55 to 190 minutes of death from five patients with Parkinson's disease caused no pathological symptoms in monkeys, rabbits, rats, guinea-pigs, mice, and pigeons. No histological changes were demonstrable in the brains of these animals. These results seem to warrant the conclusion that Lewy bodies are not to be included among the inclusion bodies caused by virus infections, which inclusions consist of a colony of elementary particles.

Microradiography revealed no heavy metals in the Lewy bodies.

Histochemical examination showed that the central core consists of proteins containing aromatic alpha-amino-acids.

We have appreciated the very helpful advice and criticism of Prof. Dr. A. Biemond. We are also much indebted to Prof. Dr. M. T. Jansen and Dr. I. Molencar for the ultra-violet microscopic and microradiographic investigations. Thanks are due to Dr. J. James for his help in investigating nucleoproteins; to Dr. J. Hoogendijk and Dr. F. Dekking for their help in the virological studies.

This investigation was made possible partly by a grant obtained from "De Drie Lichten".

\section{REFERENCES}

Beheim-Schwarzbach, D. (1952). J. nerv. ment. Dis., 116, 619. Croissant, O., Lépine, $\dot{\mathrm{P}}$, and Wyckoff, R. W. G. (1955). Ann. Inst. Pasteur, 89, 183.

Finner, L. L., and Calvery, H. O. (1939). Arch. Path. (Chicago), 27, 433 .

Foix, C., and Nicolesco, J. (1925). Anatomie cérébrale. Les noyaux gris centraux et la région mésencéphalo-sous-optique. Masson, Paris.

Gaylord, W. H., and Melnick, J. L. (1953). J. exp. Med., 98, 157. Greenfield, J. G., and Bosanquet, F. D. (1953). J. Neurol. Neurosurg. Psychiat., 16, 213.

Hartz, P. H., and Sar, A. van der (1944). Rev. sudamer. Morf., 268

Hassler, R. (1938). J. Psychol. Neurol. (Lpz.), 48, 387.

Herzberg. K. (1934). Zbl. Bakt., I. Abt. Orig., 131, 358.

Klaue, R. (1940). Arch. Psychiat. Nervenkr., 111, 251.

Lewy, F. H. (19i3). Disch. Z. Nervenheilk, 50, 50.

- (1923). Die Lehre vom Tonus und der Bewegung. Springer, Berlin.

Morgan, C., Ellison, S. A., Rose, H. M., and Moore, D. H. (1954). J. exp. Med., 100, 195 and 301 .

Olitsky, P. K., and Harford, C. G. (1937). Amer. J. Path., 13, 729.

Pappenheimer, A. M., and Maechling, E. H. (1934). Ibid., 10, 577.

Redlich, E. (1930). Mschr. Psychiat. Neurol., 75, 129.

Rövéti, G. (1956). Ibid., 132, 347.

Sourander, P. (1956). J. Path. Bact., 72, 257.

Trétiakoff, C. (1919). Contribution à l'étude de l'anatomie pathologique du Locus niger de Soemmering. Thesis, Paris.

Valkenburg, C. T. van (1941). Ned. T. Geneesk., 85, 241.

Wachstein, M. (1949). Arch. Path. (Chicago), 48, 442.

Wolman, M. (1954). J. Path. Bact., 68, 159. 